Journal of Environmental Sciences
JOESE 5
ISSN 2090-9233
Journal homepage http://Joese.mans.edu.eg

Original Article

\title{
Anthropogenic Impacts on Water Quality of River Nile and Marine Environment, Rosetta Branch Using Geospatial Analyses
}

\author{
Ahmed M. El-Zeiny ${ }^{{ }^{*}}$; Hazem T. Abd El-Hamid ${ }^{2}$ and Muhammad A. El-Alfy ${ }^{2}$ \\ ${ }^{1}$ Environmental Studies Department, National Authority for Remote Sensing and Space Sciences (NARSS), Cairo, Egypt \\ ${ }^{2}$ Marine Pollution Department, National Institute of Oceanography \& Fisheries, Alexandria, Egypt.
}

\begin{tabular}{|c|c|}
\hline Article Info & Abstract \\
\hline $\begin{array}{l}\text { Keywords: } \\
\text { Remote sensing } \\
\text { River Nile } \\
\text { Mediterranean Sea } \\
\text { Estuary } \\
\text { Water quality }\end{array}$ & $\begin{array}{l}\text { Present research focused on studying water quality of three ecosystems in Rosetta branch; } \\
\text { fresh River Nile, estuary and Sea water based on Landsat data and samples analyses. Two } \\
\text { multispectral Landsat images dated } 26^{\text {th }} \text { of February } 2017 \text { and } 1^{\text {st }} \text { of March } 2018 \text { provided the } \\
\text { necessary spectral data to this research. Nineteen surface water samples were collected on } 18^{\text {th }} \\
\text { March } 2017 \text { and investigated for pH, EC, silicate, phosphate, nitrite, nitrate, organic matter (OM) } \\
\text { content and Nitrogen/Phosphorus ratio. The calibrated Landsat data, synchronized with the field } \\
\text { trip, was processed to produce Land use cover map (LULC), Vegetation (NDVI), built-up (NDBI) } \\
\text { and salinity indices (NDSI) to highlight the human activities in the adjacent areas. Statistical } \\
\text { analyses were carried out to correlate the existed land uses in } 2017 \text { with water quality } \\
\text { characteristics and to monitor spectral reflectance change in } 2018 \text { responding to water quality } \\
\text { change. NDVI showed positive correlations with nitrate ( } 0.416) \text {, nitrite ( } 0.517) \text {, silicate ( } 0.272) \\
\text { and N/P ratio ( } 0.345) \text { which confirmed the impact of agricultural activities on water nutrients. } \\
\text { Although urban areas occupied } 4.87 \% \text {, they contributed to water OM levels (R= } 0.488 \text { ). Means } \\
\text { of nitrite, nitrate, phosphate and N/P followed the order; Estuary }>\text { River }>\text { Sea however for OM } \\
\text { and EC, they followed the order; Sea }>\text { Estuary }>\text { River. N/P ratio ranged from } 12.91 \text { to } 31.52 \\
\text { which indicated that phosphorus is the limiting factor for bio-growth of algae in the three studied } \\
\text { environments. In this study, innovative model for calculating water phosphate was developed in } \\
2017 \text { which indicated a similar fluctuation in phosphate levels in } 2018 \text { within different locations. } \\
\text { It can be concluded that remote sensing facilitates the spatial identification of the potential } \\
\text { sources of water pollution and helps in the qualitative assessment of nutrients and organic } \\
\text { pollutant levels in water resources. }\end{array}$ \\
\hline
\end{tabular}

\section{Introduction}

Urbanization, overpopulation and industrialization increase the stress on water resources. Further, discharges from untreated sewage water cause severe water quality problems either for fresh or marine environments (El-Gammal and El-Shazely, 2008). River Nile, which is the main source of drinking water in Egypt, receives heavy load of domestic, agricultural and industrial wastes from multiple sources. It is divided into two branches namely; Damietta and Rosetta. In Rosetta Branch of the River Nile, El-Bouraie et al. (2010) identified pollution from different origins; domestic, sewage, industrial and agricultural. Rosetta branch is influenced by several industrial companies (e.g. Kafr El-Zayat City) which potentially impact and deteriorate the quality of water (Donia

*Correspondence author: narss.ahmed@gmail.com Tel.: +201007737052

E-mail address:narss.ahmed@gmail.com.-aelzeny@narss.sci.eg et al., 2003; Elhaddad and Al-Zyoud, 2017). High River discharge could have resulted in silt and nutrients loading into the estuary affecting the sea water quality, which leads to a highly turbid water column (Jayachandran et al., 2012).

Approximately $65 \%$ of the Egyptian populations are connected to drinking water supply and only $24 \%$ to sewage networks. Due to works under construction, the domestic wastewater network is expected to grow rapidly (AbdelWahaab and Badawy, 2004). Agriculture represents the major non-point source of pollution, with a number of possible impacts on the environment and human health. In many agricultural areas, contamination of surface and groundwater has originated from nitrates leaching from fertilizers, and bacteria from feed wastes and livestock. Agricultural wastes are considered as a potential diffuse source of water contamination. In Egypt, the major impacts of agriculture on water quality includes: (1) salinity changes, (2) quality deterioration owing to fertilizers and pesticides and (iii) 
probable eutrophication of water bodies owing to an increase in nutrient levels from fertilization (Drainage Research Institute, 1995).

Since the construction of the High Aswan Dam, the water quality of the River Nile is primarily dependent on the ecosystem characteristics and quality of Nasser Lake reservoir and secondary dependent on the water characteristics of the upper reaches of the Nile River. Water that is released from Nasser Lake generally shows the same global characters and the same temporal variation from every year. Downstream fluctuations in river water quality are primarily due to (1) the hydrodynamic regime of the river, (2) agricultural return flows, and (3) domestic and industrial wastewater discharges including oil wastes from boats. These changes are more obvious as the river flows through the densely urban and industrial centers of great Cairo and the Nile Delta region (ElGohary and Abdel Wahaab, 1992).

On the other hand, the directly or indirectly introduction of substances into the marine environment, including estuaries, results in harmful effects which is known as marine pollution. This pollution causes toxic effects to the living resources and marine life, risk to human health, limitation in marine activities (e.g. fishing) and deterioration of water quality. The pollution of marine environment can be caused from land-based sources e.g. untreated sewage and the dumping of wastes which reach the sea and oceans through rivers and streams, fumes from power plants and factories, etc. (Elhaddad and Al-Zyoud, 2017).

Remote sensing and GIS have been universally used in studies of water quality (e.g. Senay et al., 2001; El-Zeiny and El-Kafrawy, 2017). Boutiba and Bouakline (2011) stated that remote sensing provide spatial and temporal information that is not readily available from field investigations, thus making it possible to monitor the landscape changes effectively, identifying and evaluating water quality and problems. Many studies focused on the significant impact of land use on water pollution. Generally, built-up and agricultural lands have significant positive correlation with water pollution, which are received from point and non-point sources. Relationship between spectral data and water quality has been widely utilized in spatiotemporal and regional assessment of water pollution (El-Zeiny and El-Kafrawy, 2017). Land use is an important factor in defining the main land features and activities which might contribute to water pollution. Residential, agricultural and industrial activities are considered anthropogenic sources of pollution since pollutants are generated where people live and work (Huang et al., 2015). Further, remote Sensing and GIS are widely used for investigation of eutrophication state (El-Amier et al., 2016).

The main objective of this work is to observe and assess water quality along Rosetta branch considering fresh and saline environments, and relationships with present land uses by integrating remote sensing technology with field observations and sampling analyses.

\section{Materials and Methods}

\subsection{Study area and sampling}

The study area represents Rosetta branch of the River Nile which is located in three different governorates; Kafr ElSheikh, El-Beheira and El-Gharbia (Figure 1). The area is extended from Latitude $30^{\circ} 60^{\prime} \mathrm{N}$ to $31^{\circ} 20^{\prime} \mathrm{N}$ and from Longitude $30^{\circ} 15^{\prime} \mathrm{E}$ to $30^{\circ} 60^{\prime} \mathrm{E}$. Three different ecosystems were investigated; Mediterranean Sea (North), estuary and Fresh River Nile. In this area, the Mediterranean Sea has a great impact on the River Nile's water quality. The climatic condition of the area is typical Mediterranean environment with moderate temperature most of the year. The common wind direction is practically north-west direction most of the year that generates an overall eastward-flowing longshore current (El-Asmar and Hereher, 2010).

A total of 19 geo-referenced surface water samples were collected on $18^{\text {th }}$ of March 2017 (Table 1). Four samples were collected from Mediterranean Sea, three from the estuary and twelve from the fresh River Nile. The collected samples were transferred into the laboratory for further analyses.

Seven different water quality parameters were investigated including electric conductivity (EC), $\mathrm{pH}$, nitrite, nitrate, silicate, phosphate and organic matter (OM). Conductivity was measured using conductivity meter (Thermo Electron Corporation, S/N 088341 USA) and the results were expressed as $\mu \mathrm{m} / \mathrm{cm}$. The collected samples were filtered using $0.45 \mu \mathrm{m}$ membrane filters. In the filtered water samples, dissolved inorganic nitrogen forms $\left(\mathrm{NO}_{2}\right.$ and $\left.\mathrm{NO}_{3}\right)$, dissolved inorganic phosphorus $\left(\mathrm{PO}_{4}\right)$ and silicate $\left(\mathrm{SiO}_{4}\right)$ were determined as described by Grasshoff et al. (1999). The developed colors of the nutrient salts were measured using spectrophotometer and all concentrations were expressed as $\mu \mathrm{g} / \mathrm{l}$. Organic matter $(\mathrm{OM})$ was analyzed following the permanganate oxidation method (FAO, 1975).

\subsection{Remotely sensed data acquisition and analyses}

Free downloaded multispectral Landsat OLI images dated $26^{\text {th }}$ February 2017 and $1^{\text {st }}$ March 2018, path 177/ raw 38 were used in this study. Preprocessing procedures, including radiometric calibration and atmospheric correction, were firstly applied for calibration purposes. The calibrated images were, then, cropped to resize the area of study for further processing.

\subsubsection{Supervised Classification}

Maximum Likelihood Classification (MLC) has been widely used for supervised classification of satellite images to produce land use and land cover map (Chan et al., 2001). Field validation points were used to assess accuracy of the classification. These points were determined in the classified images and verified in the field using a GPS and the original false color images. This assessment shows the degree to which the derived image classification matches with reality (Campbell, 1996). In the present study, land use/cover map was used to identify the spatial distribution of land use which helped to define the probable sources of water pollution; i.e. urban and agriculture (El-Zeiny and El-Kafrawy, 2017). In the 
present study, the overall accuracy obtained for the classified image was $98.33 \%$.

\subsubsection{Spectral Retrieved Indices}

The calibrated Landsat image was processed to produce three spectral indices based on the empirical equations in ENVI 5.1 following Zha et al. (2003). These indices are used to quantify land uses around the sampled sites and to facilitate the statistical relationships between water quality and spectral indices.

A. Normalized Difference Built-Up Index (NDBI) highlights urban areas.

$$
N D B I=(S W I R-N I R) /(S W I R+N I R)
$$

B. Normalized Difference Vegetation Index (NDVI) is a measure of density of vegetation.

$$
N D V I=(N I R-R e d) /(N I R+R e d)
$$

C. Normalized Differential Salinity Index (NDSI) is an indicator of land affected by salinization; it is just the reverse of the NDVI.

$$
N D S I=(\operatorname{Red}-N I R) /(\operatorname{Red}+N I R)
$$

\subsection{Statistical analysis}

Pearson's correlation was used to investigate the relationships between each pairs of the studied variables by using the SPSS software package (SPSS. ver.16). One-way ANOVA and mean values for the measured variables were separated on basis of Duncan's test at 0.1 probability level, using COSTAT 6.3 program. Cluster analyses based on BrayCurtis similarity index were conducted using the PAST program (multivariate statistical package, ver. 1.72). Further, correlation coefficient was used to identify the relationship between land uses expressed in spectral indices and water quality parameters.

The satellite image acquired on $1^{\text {st }}$ of March 2018 was calibrated to obtain a reflectance data to be integrated with 2017 image to assess the temporal changes in the spectral values as a result of water quality changes. This was achieved by obtaining the corresponding reflectance values at the sampling sites in 2017 and 2018. For this purpose, seven multispectral bands were utilized; B1 $(0.4430 \mu \mathrm{m})$, B2 $(0.4526 \mu \mathrm{m}), \mathrm{B} 3(0.5613 \mu \mathrm{m}), \mathrm{B} 4(0.6546 \mu \mathrm{m}), \mathrm{B} 5(0.8646$ $\mu \mathrm{m})$, B6 $(1.6090 \mu \mathrm{m})$ and B7 $(2.2010 \mu \mathrm{m})$. Regression analyses were employed for empirical equation generation using Excel software 2017.

\section{Results and Discussions}

\subsection{Land use/ cover map (LULC)}

There is a significant effect of land use on water quality; sites where agricultural, industrial and urban activities are practiced are considered anthropogenic sources of water pollution. Pollutants are generated where people live and work, therefore the spatial identification of various land uses is necessary for assessing the probable sources of water pollution. The MLC was used to create seven different LULC classes; agriculture, bare land, built-up, sabkha, water, water logging and wetland (Figure 2). The agricultural land dominated the whole study area $\left(1393.63 \mathrm{~km}^{2}, 76.59 \%\right)$; which might have an impact on water quality of the River Nile through the uncontrolled applications of chemical fertilizers. Saline and fresh water resources, including Mediterranean Sea and River Nile, were classified as "water" which represents the second dominant class in LULC map $\left(204.26 \mathrm{~km}^{2}, 11.23\right.$ $\%)$. The third class was "built-up" areas $\left(88.59 \mathrm{~km}^{2}, 4.87 \%\right)$ which are distributed in several separate parts in the whole study area and are considered as a significant source of water pollution through the wastewater discharge into water bodies. In the northern parts, close to the Mediterranean Sea, three classes were mapped; Sabkha, water logging and wetlands recording $2.02 \mathrm{~km}^{2}(0.11 \%), 7.31 \mathrm{~km}^{2}(0.40 \%)$ and $6.82 \mathrm{~km}^{2}$ $(0.37 \%)$, respectively. The influence of Sea water intrusion and higher water table levels are the main factors inducing the formation of these classes.

\subsection{Water Quality}

The investigated sites were divided into three different ecosystems; the River water of Rosetta branch (fresh sector), estuary (saline/brackish sector) and Mediterranean Sea (saline sector). Discharge of wastewater from domestic, agricultural and industrial activities represents the main sources of water pollution and deterioration of water quality in the study area. Good water quality is vital for ecosystem of both fresh and marine water. For assessing water quality, determination of parameters is important as $\mathrm{pH}, \mathrm{EC}, \mathrm{OM}$ and different nutrients (Table 2 and Figure 3 (a-d)).

Electrical conductivity (EC) recorded a remarkable fluctuation in its mean values within the studied environments recording $113350,29266.67$ and $764.3 \mu \mathrm{s} / \mathrm{cm}$ for Sea, estuary and fresh River Nile, respectively. It follows the following order; Sea $>$ Estuary $>$ River. Downstream area contained saline water where salinity is remarkably decreasing towards upstream. The estuary area has the characteristics of both environments (Sea and River) in regard of physicochemical characteristics of water. Present EC levels in fresh River Nile of Rosetta branch $(682-813 \mu \mathrm{s} / \mathrm{cm})$ is higher than recorded by Ezzat et al., $2012(375.5-803.5 \mu \mathrm{s} / \mathrm{cm})$. Further, estuary EC average $(29266.67 \mu \mathrm{s} / \mathrm{cm})$ is higher than recorded by ElAmier et al., $2015(18663.2 \mu \mathrm{s} / \mathrm{cm})$. Elevated levels of EC in the River Nile might be attributed to the increased levels of wastewater discharge as a result of urban area increase.

Weak alkaline water samples were recorded within the three studied environments recording mean values of $8.2,8.5$ and 8.1 for Mediterranean, estuary and Fresh River, respectively. The more alkaline water samples were recorded in the estuary area. Present $\mathrm{pH}$ levels in the River Nile (8.06$8.44)$ are coinciding with the threshold limits identified in the Egyptian Law No. 48/1982 (7-8.5) but higher than recorded by Ezzat et al. (2012) in the same area (7.45-7.9). The $\mathrm{pH}$ measured in estuary (8.5) is higher than recorded by El-Amier et al., 2015 (7.96) and Mostafa \& Peters, 2016 (8.05). Present level of $\mathrm{pH}(8.13-8.29)$ in the Sea is matching with the range recorded by Abdel-Halim and Aly-Eldeen (2016) during winter season (8.03-8.35).

Similar fluctuation in levels of $\mathrm{NO}_{3}$ and $\mathrm{NO}_{2}$ was observed within the studied environments, recording the 
highest mean levels in estuary (553.5 and $228.35 \mu \mathrm{g} / \mathrm{l})$ followed by fresh River section ( 495.78 and $110.39 \mu \mathrm{g} / \mathrm{l})$ since the lowest levels were observed in the Sea water samples (41.45 and $30.5 \mu \mathrm{g} / \mathrm{l}$ ), respectively. The extensive utilization of inorganic fertilizers containing nitrogen is one of the significant sources of nitrate ions in water resources (Taha et al., 2004). However, the elevated levels of $\mathrm{NO}_{3}$ an $\mathrm{NO}_{2}$ in the estuary environment were highly influenced by the fish cages usage in this area. It was noticeable that the high concentrations of both ions were at El-Mahmoudia area due to drainage water discharge into this area. Levels of $\mathrm{NO}_{2}$ in the River Nile are matching with findings of Ezzat et al. (2012) in the same area $(\leq 200 \mu \mathrm{g} / \mathrm{l})$ except site number $8(594.35 \mu \mathrm{g} / \mathrm{l})$. Elevated $\mathrm{NO}_{2}$ level at site 8 might be due to the activities practiced in the lifting station adjacent to this site. On the other hand, present findings of $\mathrm{NO}_{3}$ in the River Nile of Rosetta $(115.85-1383.25 \mu \mathrm{g} / \mathrm{l})$ are within accepted limits of the Egyptian Law No 48/1982 $(\leq 45000 \mu \mathrm{g} / \mathrm{l})$ and lower than findings of Ezzat et al., $2012(5710-37150 \mu \mathrm{g} / \mathrm{l})$. Present $\mathrm{NO}_{3}$ average in estuary $(553.5 \mu \mathrm{g} / \mathrm{l})$ is significantly lower than findings of Mostafa and Peters, $2016(10300 \mu \mathrm{g} / \mathrm{l})$ at the same area.

On the other hand, the recorded mean values of $\mathrm{PO}_{4}$ were 3.21, 17.56 and $16.84 \mu \mathrm{g} / 1$ for Mediterranean, estuary and Fresh River, respectively. The lowest mean value was recorded in the marine environment which is related to the increasing plankton that feed on nutrient causing depletion to its concentration (Abd El-Hamid, 2017). High $\mathrm{PO}_{4}$ levels were recorded in the estuary and fresh water whereas the domestic detergent and industrial sewage water are considered important sources of phosphorus in natural water (Taha et al., 2004). Present concentrations of $\mathrm{PO}_{4}$ in the River Nile samples (7.36-27.56 $\mu \mathrm{g} / \mathrm{l})$ are coinciding with records of Ezzat et al., $2012(<200 \mu \mathrm{g} / \mathrm{l})$ in the same area.

Silicate recorded mean values of 614.25, 2009 and 290.5 $\mu \mathrm{g} / \mathrm{l}$ at fresh, estuary and Sea water, respectively. The high levels of silicate in water resources may be attributed to the degradation of dead diatoms and to increase in silicon solubility. The slight increase in silicate levels depends on the degradation of the diatoms and other microorganisms (Bailey - Watts, 1976).

Mean values of $\mathrm{OM}$ were 39,36 and $37.16 \mathrm{mg} / \mathrm{l}$ for Mediterranean, estuary and Fresh River, respectively. For fresh water, high levels of OM may be attributed to human activities, industrial wastewater and dead aquatic plants. For estuary ecosystem, OM can be received from two major pathways; Allochthonous and Autochthonous. The Allochthonous $\mathrm{OM}$ is originated outside the estuary and transported into the estuary from watershed runoff and riverine inflow (i.e. primary source). Further, it might also originate from sea waters through tidal inlets (i.e. secondary source). It is generated generally through photosynthesis process by primary producers or by benthic OM regeneration. In estuary habitats, the dominant primary producers are phytoplankton, sea grasses, epiphytes, benthic microalgae and submerged aquatic vegetation (Nixon, 1995; Paerl, 1997).

Eutrophication is the process of increasing the rate of OM supply and nutrients to an ecosystem. Nutrient sources can be basically grouped into two categories; point and non-point sources. The point sources include waste-water treatment plants, sewage outfalls, industrial waste-water and storm water drains. Nonpoint sources are mainly watershed runoff, ground water, and atmospheric deposition (Pinckney et al., 2014).

The N/P ratio gives an indication to the limiting factor responsible for controlling eutrophication in aquatic environment. N/P ratio was calculated from the concentrations of nitrogen as nitrate and phosphorus as phosphate. The N/P ratio can be classified as follows; $<5$ (N-limitation conditions), 5-10 (either $\mathrm{N}$ or $\mathrm{P}$ limitation condition) or $>10$ (P- limitation condition) (Smith and Shapiro, 1980). In this study, mean values of N/P ratio were 12.91, 31.52 and 27.30 for Mediterranean, estuary and fresh water environments, respectively. This gives an indication that phosphorus is the limiting factor for bio-growth of algae in the studied environments.

\subsection{Statistical analyses}

The results of correlation coefficient (r) were evaluated by Ramadan (2003) as follow; 0.0 (no), 0.3-0.5 (low), 0.5-0.7 (medium), 0.7-0.9 (high) and 0.9-1 (very high). The three selected indices (NDVI, NDBI and NDSI) were used to assess the relationship between water quality and land use. Agricultural activities which have an impact on water quality were assessed using the vegetation index (NDVI) which identified the density of vegetation around the sampled sites. To assess the effect of human activities and domestic wastewater discharges on water quality, built-up index (NDBI) was used. This index identifies the urban areas around the investigated sites. On the other hand, relationship between land salinization and water quality was assessed using the salinity index; NDSI (Figure 4).

Table (3) shows the correlation coefficient between water quality characteristics and spectral land use indices. Silicates contributed to water salinity and showed a significant positive correlation (0.827) with electric conductivity (EC). Pollutants from the same source exhibited positive correlations with each other and with the source of pollution. Therefore, positive correlations were observed between EC and silicate (0.827), nitrate and nitrite $(0.806)$, nitrate and silicates $(0.460)$, nitrite and silicate $(0.721), \mathrm{N} / \mathrm{P}$ and silicate $(0.334), \mathrm{N} / \mathrm{P}$ ratio and nitrite (0.738), N/P and nitrate (0.897).

One of the significant sources of water nutrients in study area is the agricultural activities, therefore NDVI showed positive correlations (low to medium) with nitrate $(0.416)$, nitrite $(0.517)$, silicate $(0.272)$ and $\mathrm{N} / \mathrm{P}$ ratio $(0.345)$. The extensive application of fertilizers in the agricultural areas significantly participated to water pollution by nitrogenous and phosphorus compounds (Elbeih and El-Zeiny, 2018).

On the other hand, sewage wastewater discharge from urban areas are considered one of the sources of water organic pollution thus a positive correlation was observed between NDBI and OM (0.488). Land degraded by salinization showed a low positive correlation with OM levels in water (0.246).

It was obvious that pollutants from the same sources are positively and significantly correlated (i.e. $\mathrm{NO}_{2}, \mathrm{NO}_{3}$ ). The cluster analysis indicated similarity in parameter levels in each environment (Figure 5). In regard of the mean values for investigated parameters between different habitats, ANOVA statistical analysis was calculated (Table 4). ANOVA results 
showed high significance $(\mathrm{p}<0.05)$ for electric conductivity and silicates, moderate significance for $\mathrm{pH}$, phosphate, NDSI and NDVI and non-significance for nitrate, organic matter and NDBI.

\subsection{Relationship between spectral data and water quality}

The correlation coefficiant between water quality and spectral reflectance bands is shown in table (5). Significant correlations were observed between spectral bands with electric conductivity, nitrate and phosphate. For EC, significant positive correlations were recorded with B1, B2, $\mathrm{B} 3$ and B4 recording $0.96,0.97,0.97$ and 0.80 respectively. However, it showed significant negative correlations with B5 and B6 recording -0.92 and -0.79 , respectively. Nitrate showed sigificant negative correlations with B1 (-0.61), B2 ($0.59)$ and B3 (0.95). Further, phosphate showed significant correlations with all visible bands (B2-B4)

These significant relations could be used for calculating water quality. This simply means that the spectral image can be converted into water quality characteristics. This advantage has been used in this study, based on regression analyses, to build an innovative model for phosphate in water (Figure 6). Phosphate was selected due to its high importance in water as a pollutant and as a bio-factor for the growth of algae. The model (algorithm) was generated based on the spectral reflectance of band 2 (Blue, $0.4526 \mu \mathrm{m}$ ) which exhibited a high positive correlation with water phosphate $(0.720)$. The predicted phosphate (calculated from the model) showed also a high positive correlation with the laboratory measured phosphate (0.721). Formula of the generated algorithm is;

\section{Phosphate $(p p b)=-719.44 *$ Band $2(0.4526 \mu \mathrm{m})+86.981$}

Water is a dynamic environment; its quality is changeable and significantly impacted by different natural and anthropogenic factors. Therefore, the spectral reflectance of water varies according to water quality. Although there was a temporal change in the spectral values of each band in the same pixels (Figure 7), they were highly correlated $(>0.6)$ in most of the investigated bands between 2017 and 2018 (0.39).

The developed model for phosphate was used to monitor the changes in its levels between 2017 and 2018. A similar fluctuation in phosphate levels $(R=0.79)$ was observed between 2017 and 2018 (Figure 8). This confirms that pollution sources have a continuous impact on water quality in the study area.

The generated model requires more assessment and validation to be applicable in similar environments. Although remote sensing is not so accurate as laboratory investigations in water quality studies, it gave the advantage of spatiotemporal assessments in inacessible areas or in areas which are difficult or impossible to be reached for sampling and analyses using the conventional methods.

Table 1. Description of water sampling locations

\begin{tabular}{|c|c|c|c|}
\hline \multirow{2}{*}{ No } & \multicolumn{2}{|c|}{ Coordinates } & \multirow{2}{*}{ Description } \\
\hline & $\mathbf{X}$ & $\mathbf{Y}$ & \\
\hline \multicolumn{4}{|r|}{ Mediterranean Sea Samples } \\
\hline 1 & 31.48 & 30.39 & East of downstream point \\
\hline 2 & 31.47 & 30.36 & Downstream point \\
\hline 3 & 31.46 & 30.36 & West of downstream point \\
\hline 4 & 31.45 & 30.36 & West of downstream point \\
\hline \multicolumn{4}{|r|}{ Estuary Samples } \\
\hline 5 & 31.37 & 30.43 & Rasheed bridge, fisheries, closest point to the Sea \\
\hline 6 & 31.37 & 30.44 & Ezbet Henedy, agricultural activities are practiced \\
\hline 7 & 31.35 & 30.45 & Industrial area, brick factories, some buildings, fisheries \\
\hline \multicolumn{4}{|r|}{ Fresh River Nile Samples } \\
\hline 8 & 31.30 & 30.52 & Close to lifting station of El-Deba \\
\hline 9 & 31.19 & 30.52 & Residential area, close to electricity station of El-Mahmodia \\
\hline 10 & 31.13 & 30.64 & Close to Desouk bridge, adjacent to residential area \\
\hline 11 & 31.12 & 30.65 & Beneath Desouk bridge, close to fishing boats \\
\hline 12 & 31.11 & 30.66 & A complain received from the discharge of domestic and industrial wastewater in close areas, brick factories \\
\hline 13 & 31.10 & 30.69 & Very close to residential areas, few vegetation, Nile is very narrow at this area, Nile Rose plants \\
\hline 14 & 31.08 & 30.71 & The whole surrounding area is residential which is very close to the Nile, turbid water, Nile Rose plants \\
\hline 15 & 31.07 & 30.72 & Clear water, close to a worship place (Mosque) \\
\hline 16 & 31.03 & 30.72 & Urban area, close to commercial places (coffee shop and supermarket) \\
\hline 17 & 31.01 & 30.74 & At Kafr El-Sheikh boundaries, fishes were dead and flowing on water surface \\
\hline 18 & 30.92 & 30.78 & Few vegetation, close to Kafr El-Zayat, urban area \\
\hline 19 & 30.90 & 30.77 & Urban area, closest point to Kafr El-Zayat \\
\hline
\end{tabular}


Journal of Environmental Sciences, 2018; Vol. 47, No. 3-4 :89-101

Table 2. Water quality characteristics in the three studied ecosystems

\begin{tabular}{|c|c|c|c|c|c|c|c|c|c|}
\hline \multirow{2}{*}{$\begin{array}{l}\text { Water } \\
\text { Type }\end{array}$} & \multirow{2}{*}{ No. } & \multirow{2}{*}{$\mathrm{EC}(\mu \mathrm{s} / \mathrm{cm})$} & \multirow{2}{*}{ pH } & \multicolumn{4}{|c|}{ Nutrients $(\mu \mathrm{g} / \mathrm{l})$} & \multirow{2}{*}{ OM (mg/l) } & \multirow{2}{*}{$\mathrm{N} / \mathrm{P}$ ratio } \\
\hline & & & & $\mathrm{NO}_{3}$ & $\mathrm{NO}_{2}$ & $\mathrm{SiO}_{4}$ & $\mathrm{PO}_{4}$ & & \\
\hline \multirow{5}{*}{ 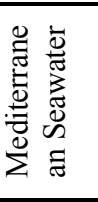 } & 1 & 119100 & 8.25 & 62.76 & 23.77 & 619 & 5.21 & 72 & 12.05 \\
\hline & 2 & 97000 & 8.13 & 40.24 & 68.51 & 767 & 4.59 & 28 & 8.77 \\
\hline & 3 & 118800 & 8.3 & 31.4 & 16.89 & 642 & 2.14 & 24 & 14.67 \\
\hline & 4 & 118500 & 8.29 & 31.4 & 12.83 & 429 & 0.92 & 32 & 34.13 \\
\hline & Mean & 113350 & 8.2 & 41.45 & 30.5 & 614.25 & 3.21 & 39 & 12.91 \\
\hline \multirow{4}{*}{ 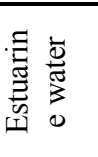 } & 5 & 24800 & 8.67 & 581.75 & 315.95 & 2583 & 26.96 & 40 & 21.58 \\
\hline & 6 & 29600 & 8.41 & 661.05 & 245.55 & 1638 & 14.08 & 30 & 46.95 \\
\hline & 7 & 33400 & 8.47 & 417.7 & 123.55 & 1806 & 11.64 & 38 & 35.88 \\
\hline & Mean & 29266.67 & 8.5 & 553.5 & 228.35 & 2009 & 17.56 & 36 & 31.52 \\
\hline \multirow{13}{*}{ 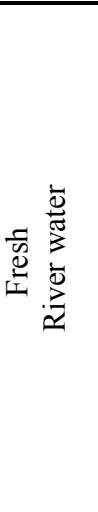 } & 8 & 740 & 8.42 & 1383.25 & 594.35 & 1589 & 11.64 & 18 & 118.84 \\
\hline & 9 & 682 & 8.28 & 765.35 & 79.75 & 182 & 12.26 & 32 & 62.43 \\
\hline & 10 & 714 & 8.13 & 304.7 & 70.4 & 105 & 18.38 & 8 & 16.58 \\
\hline & 11 & 719 & 8.44 & 175.3 & 71.95 & 427 & 7.36 & 40 & 23.82 \\
\hline & 12 & 770 & 8.09 & 437 & 54.75 & 224 & 15.92 & 6 & 27.45 \\
\hline & 13 & 870 & 8.17 & 223 & 75.1 & 77 & 23.28 & 14 & 9.58 \\
\hline & 14 & 777 & 8.06 & 324.4 & 51.6 & 266 & 15.32 & 110 & 21.17 \\
\hline & 15 & 813 & 8.05 & 360.85 & 79.75 & 140 & 27.56 & 30 & 13.09 \\
\hline & 16 & 811 & 8.19 & 313.45 & 86 & 182 & 24.5 & 70 & 12.79 \\
\hline & 17 & 791 & 8.11 & 348.9 & 45.35 & 35 & 15.92 & 20 & 21.92 \\
\hline & 18 & 771 & 8.14 & 115.85 & 51.6 & 77 & 17.16 & 30 & 6.75 \\
\hline & 19 & 714 & 8.12 & 765.35 & 64.15 & 182 & 12.86 & 68 & 59.51 \\
\hline & Mean & 764.3 & 8.1 & 459.78 & 110.39 & 290.5 & 16.84 & 37.16 & 27.30 \\
\hline
\end{tabular}

Table 3. Correlation coefficient analyses between water quality and spectral indices

\begin{tabular}{|c|c|c|c|c|c|c|c|c|c|c|c|}
\hline Parameter & EC & pH & Nitrate & Nitrite & Silicate & Phosphate & O.M & NDSI & NDVI & NDBI & $\begin{array}{c}\mathrm{N} / \mathrm{P} \\
\text { ratio }\end{array}$ \\
\hline $\mathrm{EC}$ & 1 & & & & & & & & & & \\
\hline $\mathrm{pH}$ & 0.192 & 1 & & & & & & & & & \\
\hline Nitrate & 0.106 & 0.173 & 1 & & & & & & & & \\
\hline Nitrite & 0.292 & 0.144 & 0.806 & 1 & & & & & & & \\
\hline Silicate & 0.827 & 0.229 & 0.46 & 0.721 & 1 & & & & & & \\
\hline Phosphate & -0.016 & -0.353 & -0.28 & -0.069 & -0.002 & 1 & & & & & \\
\hline O.M & -0.02 & -0.339 & -0.086 & -0.185 & -0.044 & -0.03 & 1 & & & & \\
\hline NDSI & -0.273 & 0.033 & -0.416 & -0.517 & -0.272 & -0.085 & 0.246 & 1 & & & \\
\hline NDVI & 0.273 & -0.033 & 0.416 & 0.517 & 0.272 & 0.085 & -0.246 & -1 & 1 & & \\
\hline NDBI & -0.355 & -0.006 & -0.332 & -0.516 & -0.392 & 0.032 & 0.488 & 0.744 & -0.744 & 1 & \\
\hline $\mathrm{N} / \mathrm{P}$ ratio & -0.221 & 0.329 & 0.897 & 0.738 & 0.334 & -0.171 & -0.096 & -0.345 & 0.345 & -0.135 & 1.000 \\
\hline
\end{tabular}

Table 4. One way ANOVA style of water quality parameters among the different habitats at $(\mathrm{P}<0.05)$

\begin{tabular}{|c|c|c|c|c|c|}
\hline Parameter & Seawater & Estuary water & Freshwater & F-value & P-value \\
\hline $\mathrm{EC}$ & $111433.33^{\mathrm{a}}$ & $29266.27^{b}$ & $774.33^{\mathrm{c}}$ & 169.94 & $0.00^{* * *}$ \\
\hline $\mathrm{pH}$ & $8.24^{\mathrm{b}}$ & $8.52^{\mathrm{a}}$ & $8.20^{b}$ & 8.2 & $0.19^{*}$ \\
\hline Nitrate & $34.35^{b}$ & $553.5^{\mathrm{a}}$ & $388.07^{\mathrm{ab}}$ & 4.56 & $0.63^{\mathrm{ns}}$ \\
\hline Nitrite & $32.74^{b}$ & $228.35^{\mathrm{a}}$ & $68.82^{b}$ & 9.14 & $0.02^{*}$ \\
\hline Silicate & $612.66^{b}$ & $2009^{a}$ & $112^{b}$ & 30.3 & $0.0007^{* * *}$ \\
\hline Phosphate & $2.55^{\mathrm{b}}$ & $17.56^{\mathrm{a}}$ & $17.57^{\mathrm{a}}$ & 6.65 & $0.03^{*}$ \\
\hline $\mathrm{OM}$ & $28^{\mathrm{a}}$ & $36^{\mathrm{a}}$ & $25.33^{\mathrm{a}}$ & 1.96 & $0.28^{\mathrm{ns}}$ \\
\hline NDBI & $-0.22^{\mathrm{a}}$ & $0.20^{\mathrm{a}}$ & $-0.11^{\mathrm{a}}$ & 0.77 & $0.50^{\mathrm{ns}}$ \\
\hline NDSI & $0.17^{\mathrm{a}}$ & $-0.26^{b}$ & $0.31^{b}$ & 6.82 & $0.03^{*}$ \\
\hline NDVI & $-0.17^{b}$ & $0.26^{\mathrm{a}}$ & $0.31^{\mathrm{a}}$ & 6.82 & $0.03^{*}$ \\
\hline
\end{tabular}


Journal of Environmental Sciences, 2018; Vol. 47, No. 3-4 :89-101

Table 5. Correlation between spectral reflectance bands and water quality

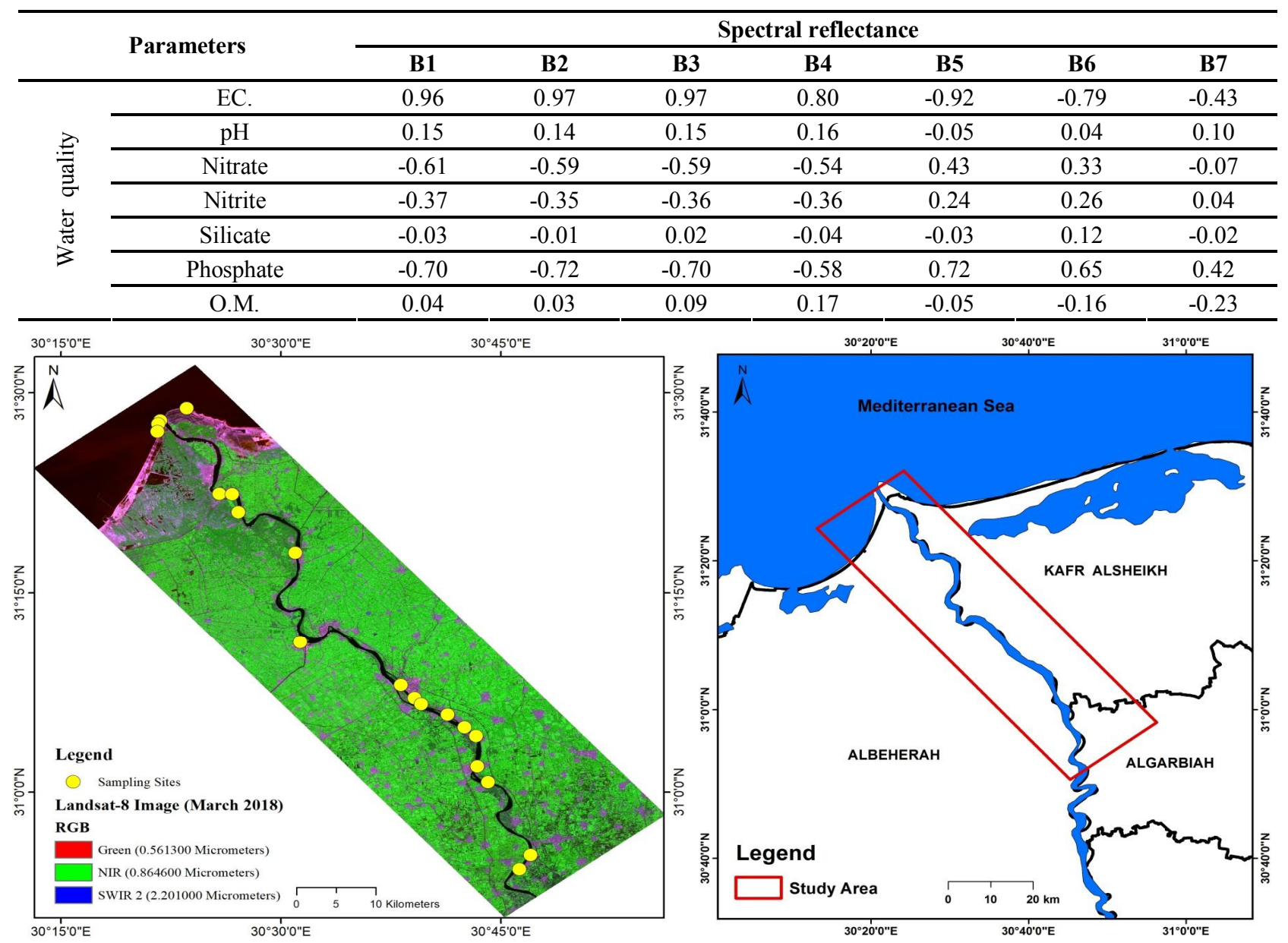

Fig. 1. Location map showing the area of study and the sampled locations

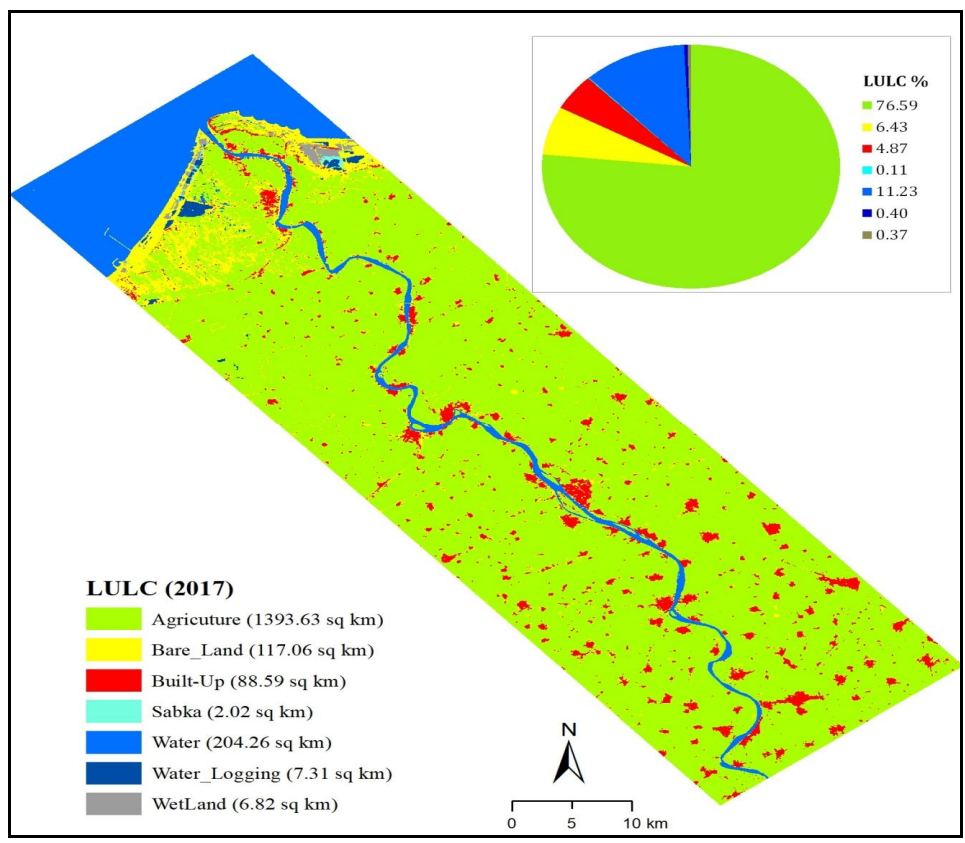

Fig. 2. Up-to-date LULC map for the study area 
Journal of Environmental Sciences, 2018; Vol. 47, No. 3-4 :89-101
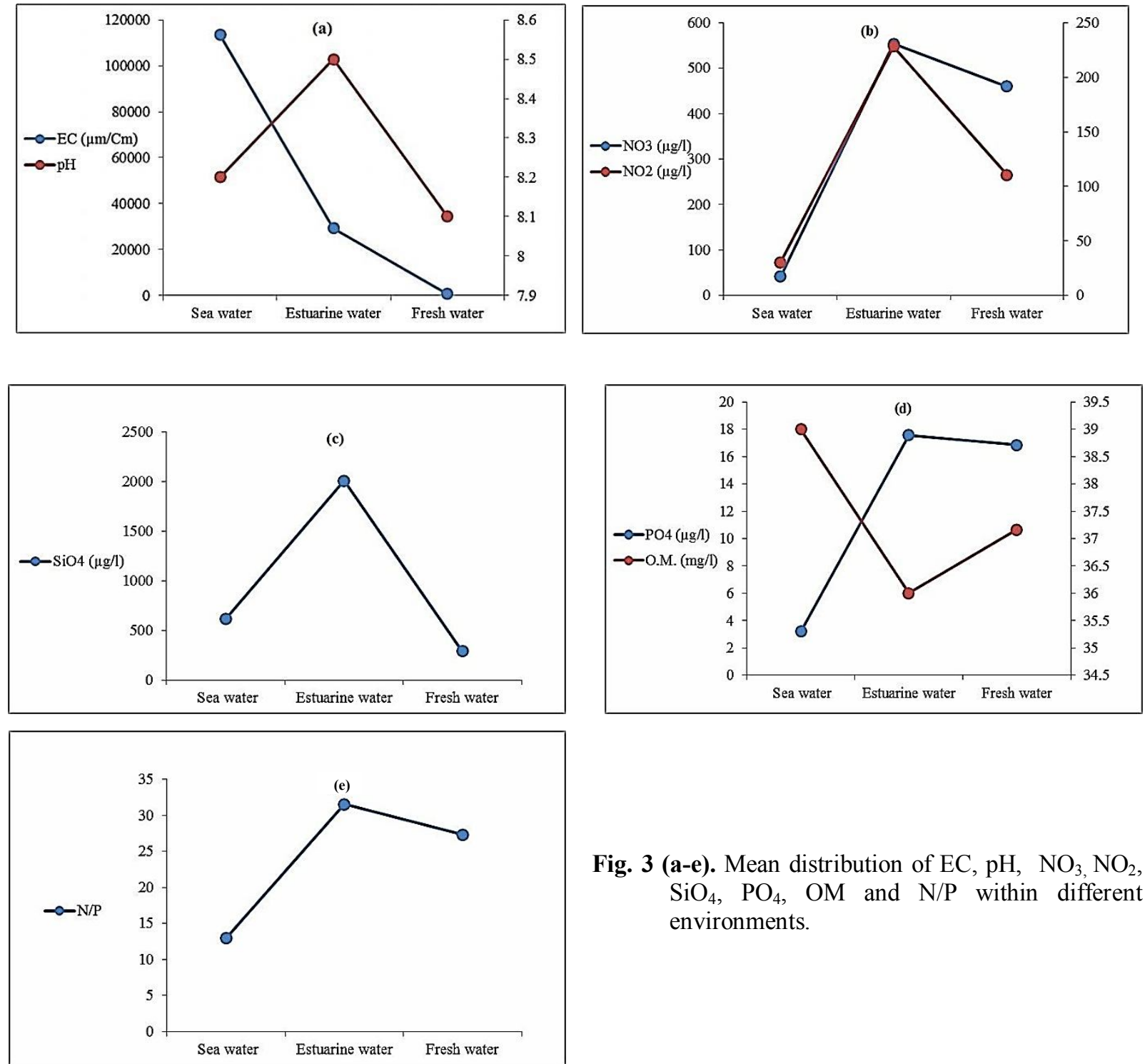

Fig. 3 (a-e). Mean distribution of $\mathrm{EC}, \mathrm{pH}, \mathrm{NO}_{3}, \mathrm{NO}_{2}$, $\mathrm{SiO}_{4}, \mathrm{PO}_{4}, \mathrm{OM}$ and $\mathrm{N} / \mathrm{P}$ within different environments.
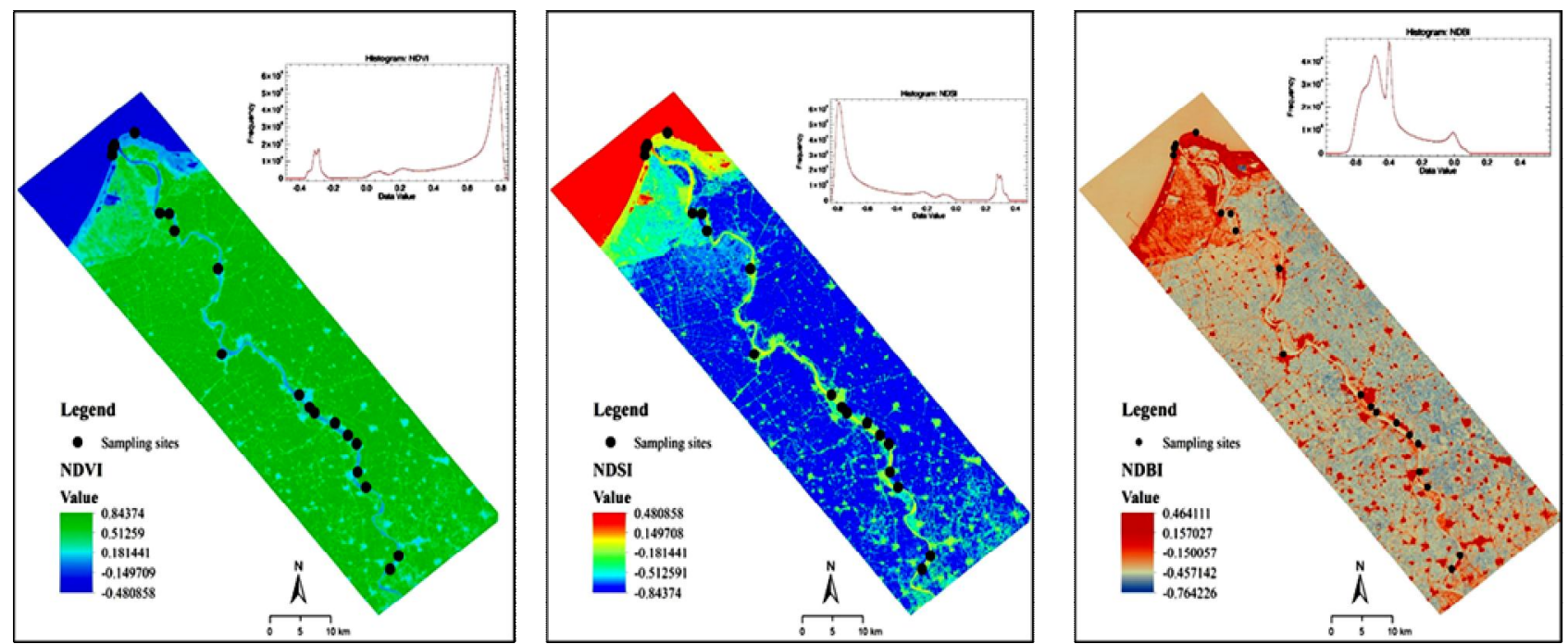

Fig. 4. Spatial distribution maps of NDVI, NDSI and NDBI in the study area 


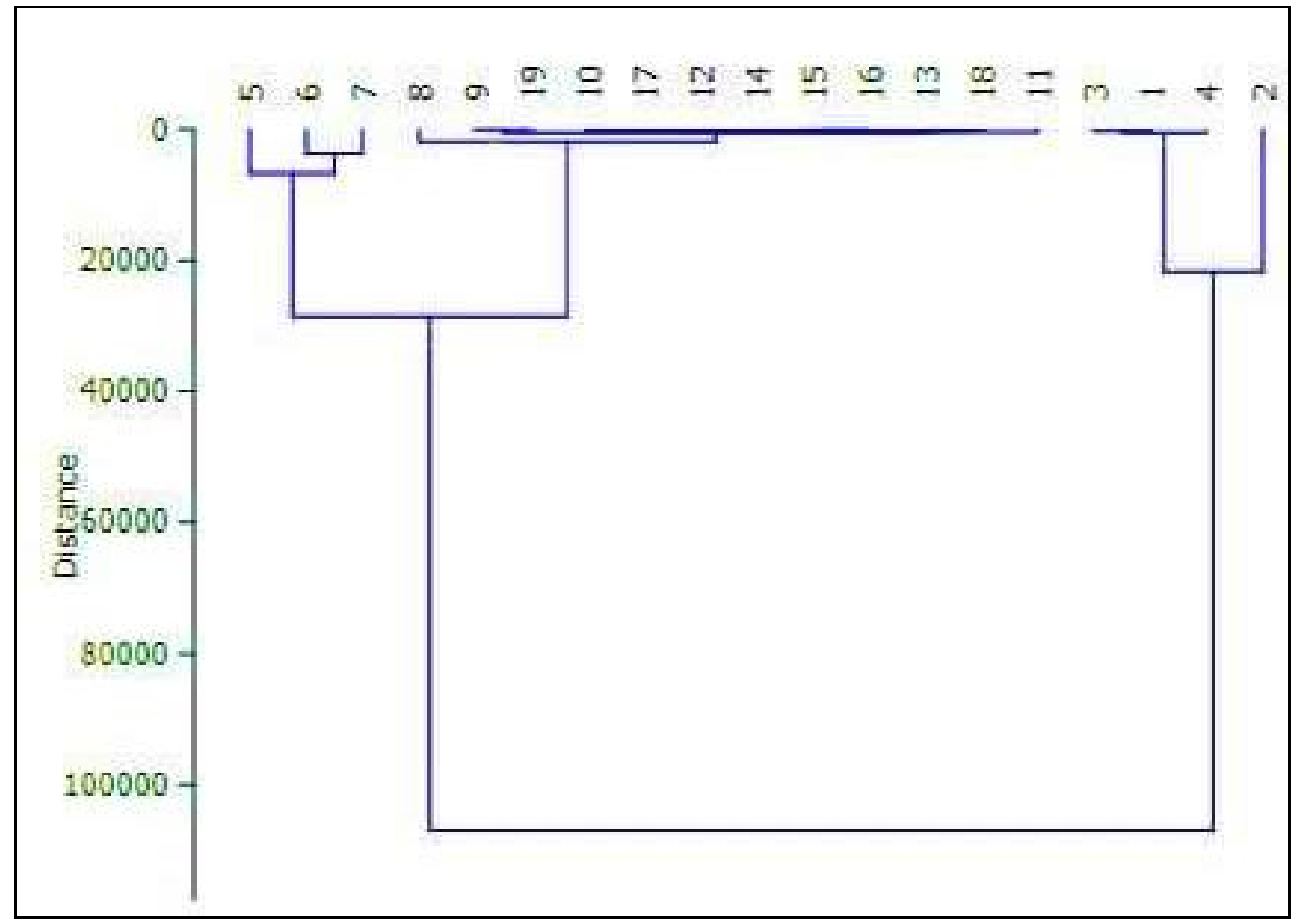

Fig. 5. Cluster analysis among water sampling stations within different environments

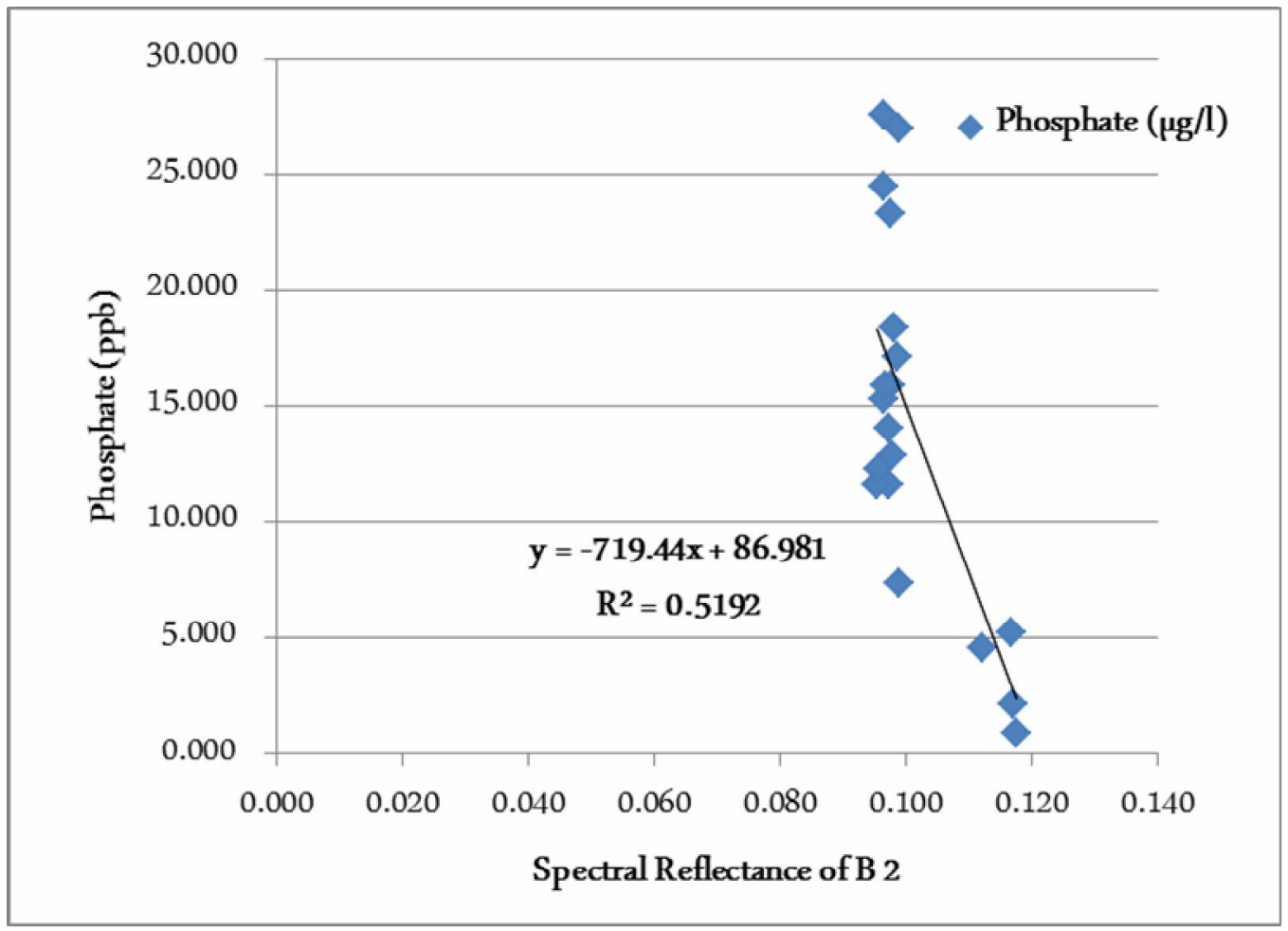

Fig. 6. Regression analysis between reflectance of blue band and phosphate 


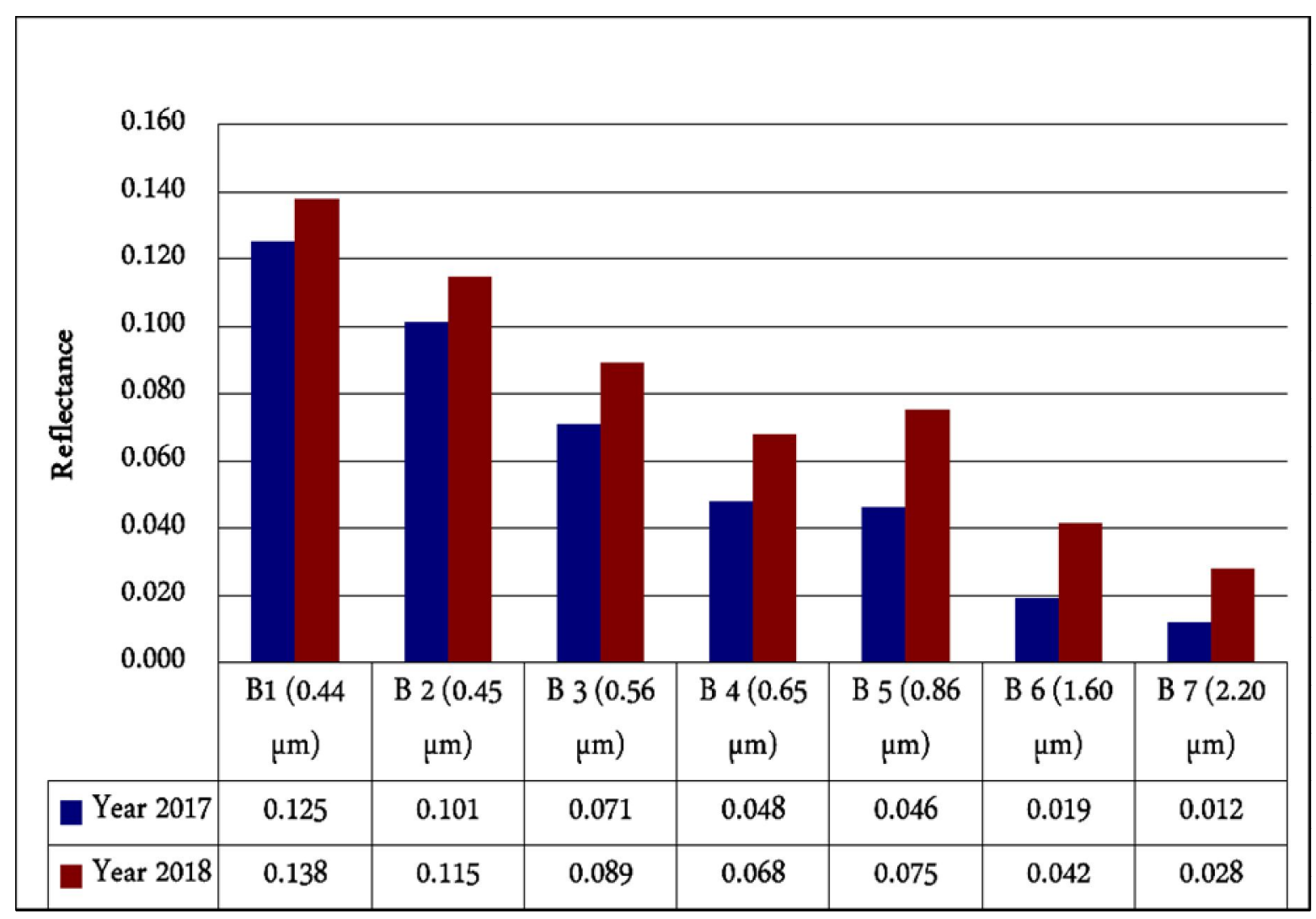

Fig. 7. Temporal change in spectral reflectance average within the sampled locations

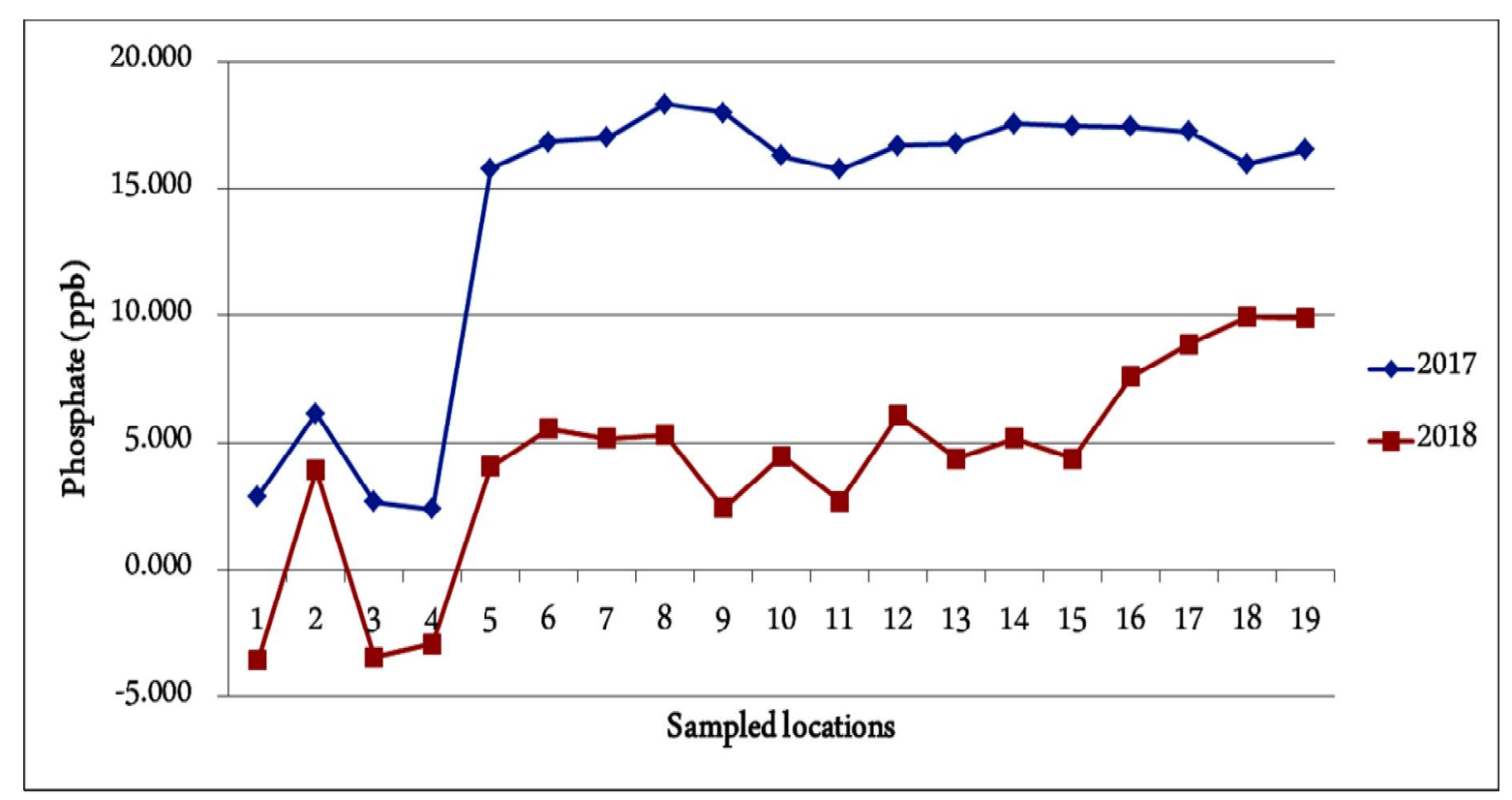

Fig. 8. Monitoring changes in phosphate between 2017 and 2018 


\section{Conclusion}

The present research is an attempt to explore the impact of land uses, extracted from satellite Landsat data, on water quality in three ecosystems (fresh, estuary and saline) in Rasheed branch area, Egypt. Various fluctuations of water quality characteristics $\left(\mathrm{pH}, \mathrm{EC}, \mathrm{NO}_{2}, \mathrm{NO}_{3}, \mathrm{SiO}_{4}, \mathrm{PO}_{4}\right.$ and $\mathrm{OM}$ ) were observed in the studied environments as a result of the severity and the kind of land use activities. Estuary was the most exposed area to water quality deterioration either from sea water activities (e.g. shipping, fisheries) or from the different urban and agricultural activities distributed along the Rosetta branch. It can be concluded that spectral retrieved land use indices (e.g. NDBI, NDVI) could be utilized to identify the spatial distribution of the probable water pollution sources and gives a predictive qualitative insight about nutrient and organic pollutants in water resources.

In this study, the statistical relationship between spectral data and water quality was utilized for generating an innovative model for phosphate in water. This model was developed to monitor the change in water phosphate between March 2017 and 2018. Model results showed a similar temporal fluctuation in water phosphate levels within samples which confirms the continuous impact of pollution sources on water quality.

To minimize water pollution in Rosetta branch, the study highly recommends the necessity for the reduction of using chemical fertilizers which contributed to the elevated levels of contaminants in water resources. Further, it is necessary to manage the discharge of domestic wastewater into waterways of Rosetta branch which significantly increases the organic load in water resources.

\section{Acknowledgement}

Authors acknowledge the United States Geological Survey (http://glovis.usgs.gov/) for providing Landsat data to this research.

\section{References}

Abdel-Halim, A. and Aly-Eldeen, M. (2016). Characteristics of Mediterranean Sea water in vicinity of Sidikerir Region, west of Alexandria, Egypt. Egyptian Journal of Aquatic Research, 42: 133-140

Abd El-Hamid, H. T. (2017). Studying heavy metals pollution along the Northern Delta Lakes, Egypt. M.Sc. thesis, Faculty of Sci. Damietta, Univ. Egypt. pp.56.

Abdel-Wahaab, R. and Badawy, M. (2004). Water Quality Assessment of the River Nile System: An Overview. Biomedical and Environmental Sciences, 17: 87-100.

Bailey-Watts, A. E. (1976). Planktonic diatoms and silica in Loch Leven, Kinross, Scotland: a one month silica budget. Freshwater Biology, 6: 203-213.

Boutiba, M. and Bouakline, S. (2011). Monitoring shoreline changes using digital aerial photographs, quick-bird image and DGPS topographic survey: Case of the east coast of Algiers, Algeria. European Journal of Scientific Research, 48 (3): 361-369.

Campbell, J. B. (1996). Introduction to Remote Sensing (2 $2^{\text {nd }}$ edition), Taylor and Francis, London: p. 621.

Chan, J.C.; Chan, K.P. and AGO, Yeh (2001). Detecting the nature of change in an urban environment: a comparison of machine learning algorithms. Photogramm. Eng. Remote Sens., 6: 213-225.

Donia, N.; El-Azizy, I. and Khalifa, A. (2003). Industrial Pollution Control of Rosetta Branch, Nile River, Egypt. Seventh International Water Technology Conference Egypt, 1-3 April: 235-247.

Drainage Research Institute (1995). Reuse of drainage water in the Nile delta, monitoring, modeling and analysis. Final Report, NWRC, DRI, Cairo.

El-Amier, Y. A.; Elnaggar, A. A. and El-Alfy, M. A. (2016) Investigation of Eutrophication State of Manzala and Burullus Lakes in Egypt by Using Remote Sensing and GIS. Journal of Environmental Science and Pollution Research, 2 (4):121-125.

El-Amier, Y.; Zahran, M., and Al-Mamory, S. (2015). Assessment the Physico-Chemical Characteristics of Water and Sediment in Rosetta Branch, Egypt. Journal of Water Resource and Protection, 7: 1075-1086

El-Asmar, H. and Hereher, M. (2010). Change detection of the coastal zone east of the Nile Delta using remote sensing. Environment and Earth Sciences, 62 (4): 769 777 .

Elbeih, S. F. and El-Zeiny, A. M. (2018). Qualitative assessment of groundwater quality based on land use spectral retrieved indices: Case study Sohag Governorate, Egypt. Remote Sensing Applications: Society and Environment, 10: 82-92.

El-Bouraie, M. M.; El Barbary, A. A.; Yehia, M. M. and Motawea, E. A. (2010). Heavy metal concentrations in surface river water and bed sediments at Nile Delta in Egypt. Suoseura - Finnish Peatland Society, 61(1): 112.

El-Gammal, H. A. and El Shazely, H. S. (2008). Quality Management Scenarios in Rosetta River Nile Branch, Egypt. Twelfth International Water Technology Conference, IWTC12 Alexandria, Egypt, 1-12.

El-Gohary, F. and Abdel Wahaab, R. (1992). Lake Manzala Water Quality, Impact Assessment of Sources of Pollution. UNEP/WB-Lake Manzala, Cairo.

Elhaddad, E. and Al-Zyoud, S. (2017). The quality assessment of pollution of Rosetta branch, Nile River, Egypt. Arab Journal of Geoscience, 10, pp 97.

El-Zeiny, A. and El-Kafrawy, S. (2017). Assessment of water pollution induced by human activities in Burullus Lake using Landsat 8 operational land imager and GIS. 
Egyptian Journal of Remote Sensing and Space Sciences, 20: S49-S56.

Ezzat, S.; Mahdy, H.; Abo-State, M.; Abd El Shakour, E. and El-Bahnasawy, M. (2012). Water Quality Assessment of River Nile at Rosetta Branch: Impact of Drains Discharge. Middle-East Journal of Scientific Research, 12 (4): 413-423.

FAO (1975). Report on the ad hoc expert consultation on land evaluation, Rome, Italy. World Soil Resources Report 45 , pp152.

Grasshoff, K.; Kremling, K. and Ehrhardt, M. (Eds.) (1999). Methods of Seawater Analysis. $3^{\text {rd }}$ ed. Wiley-VCH.

Huang, J.; Huang, Y.; Pontius, R. and Zhang, Z. (2015). Geographically weighted regression to measure spatial variations in correlations between water pollution versus land use in a coastal watershed. Ocean and Coastal Management, 103, 14e24.

Jayachandran, P. R.; Nandan, S. B. and Sreedevi, O.K. (2012). Water quality variation and nutrient characteristics of Kodungallur-Azhikode Estuary, Kerala, India. Indian Journal of Geo-Marine Sciences, 41 (2): 180-187.

Mostafa, M. and Peters, R. (2016). A Comprehensive Assessment of Water Quality at the Rosetta Branch of the Nile River, Egypt. Journal of Civil Engineering and Architecture, 10: 513-529.

Nixon, S. W. (1995). Coastal marine eutrophication: a definition, social causes, and future concerns. Ophelia, 41:199-219
Paerl, H. W. (1997). Coastal eutrophication and harmful algal blooms: importance of atmospheric deposition and groundwater as "new" nitrogen and other nutrient sources. Limnology and Oceanography, 42:11541165.

Pinckney, J. L.; Paer, H. W.; Tester, P. and Richardson, T. L. (2014).The Role of Nutrient Loading and Eutrophication in Estuarine Ecology. Environmental Health Perspectives: 699-706.

Ramadan, A. (2003). Heavy Metal Pollution and Biomonitoring Plants in Lake Manzala, Egypt. Pakistan Journal of Biological Sciences, 6 (13):11081117

Senay, G. B.; Shafique, N. A.; Autrey B.C.; Fulk, F. and Cormier, S. M. (2001). The selection of narrow wavebands for optimizing water quality monitoring on the Great Miami River, Ohio using hyperspectral remote sensor data. Journal of Spat. Hydrology, 1: 122.

Taha, A. A.; El-Mahmoudi, A. S. and El-Haddad, I. M. (2004). Pollution Sources and Related Environmental Impacts in the New Communities Southeast Nile Delta, Egypt. Emirates Journal for Engineering Research, 9 (1): 35-49.

Zha, Y.; Gao, J. and Ni, S. (2003). Use of Normalized Difference Built-Up Index in Automatically Mapping Urban Areas from TM Imagery. International Journal of Remote Sensing, 24(3): 583-594. 


\title{
الالذص العرببي \\ التأثيرات البشرية على جودة مياه نهر النيل والبيئة البحرية ، فرع رشيد \\ باستخدام التحليلات الجيومكانية
}

مازم طله عبدالهمبد؟

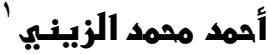

\section{محمد عبدالهادي الألفي r}

\author{
'قسم الدر اسات البيئية ،الهيئة القومية للاستشعار من البعد و علوم الفضاء، القاهرة، مصر

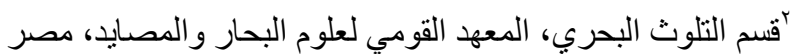

يهتم البحث بدراسة جودة المياه في ثلاث أنظمة بيئية مختلفة بفرع رشيد: مياه النيل العزبة ومياه المصب ومياه البحر

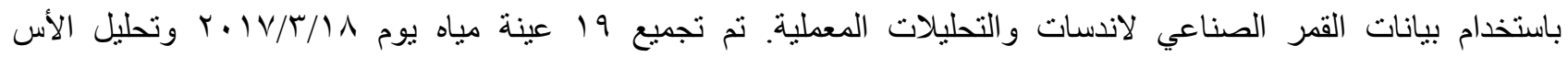
الهيدروجيني ، التوصيلية الكهربية ، السيليكات ، الفوسفات ، النيتريت ، النترات ، محتوى المادة العضوية ونسبة النيتروجين

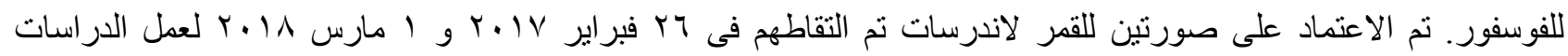
الطيفية لهذه الدراسة. تم عمل معالجة للصور لانتاج خر ائط لاستخدام الأرض ، مؤشرات الغطاء النباتي و العمران و الملوحة

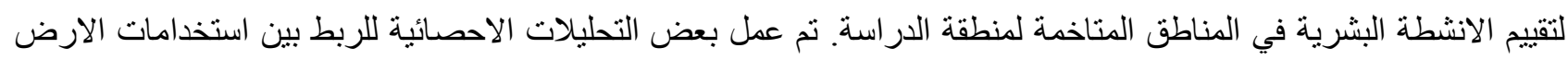

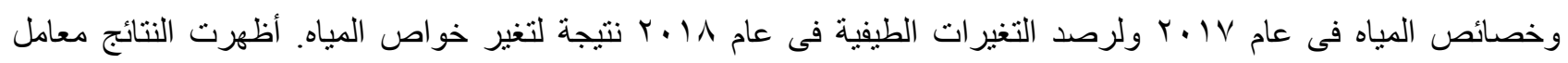
ارتباط ايجابي بين الغطاء النباتي مع النترات (7 (اء, •)، النيتريت (0.517)، السيليكات (0.272) ونسبة النيتروجين

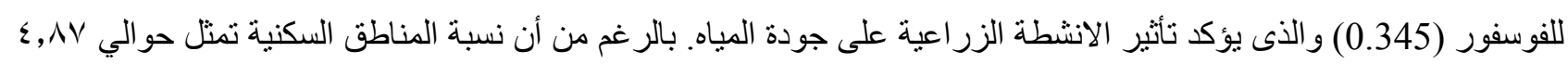

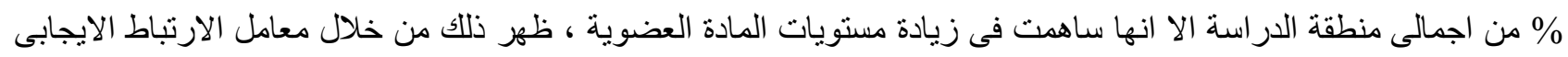
بين المادة العضوية والمناطق السكنية (1^^^) •). أظهرت متوسطات قيم النيتريت ، النترات ، الفوسفات ونسبة النيتروجين للفوسفور الترتيب التالي: المصب > المياه العذبة > مياه البحر ، بينما بالنسبة للمادة العضوية و التوصيلية الكهربية فكانت كالتالي:

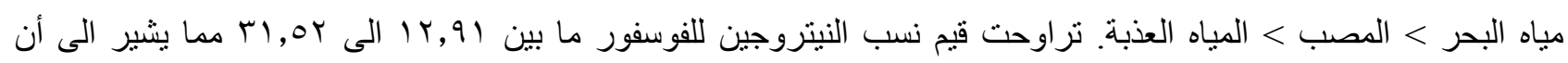

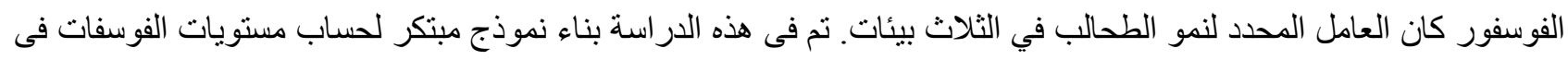

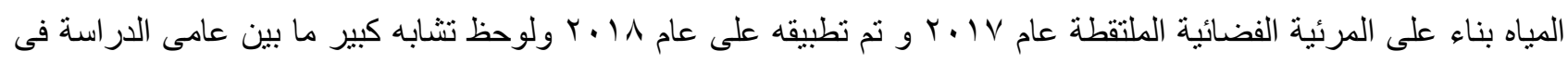
مستويات الفوسفات فى المو اقع المختلفة. يمكن استنباط أن تقنيات الاستشعار من البعد تلعب دورا هاما فى التحديد المكانى لمصادر التلوث المحتملة للمياه و في التقييم النوعى لمستويات التلوث بالمغذيات و الملوثات العضوية. 


\title{
Journal of Environmental Sciences
}

\section{JOESE 5}

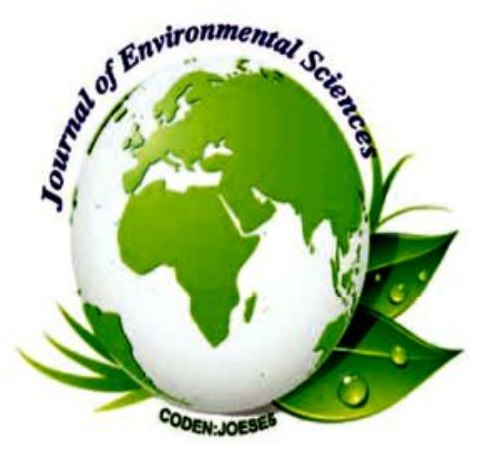

\section{Anthropogenic Impacts on Water Quality of River Nile and Marine Environment, Rosetta Branch Using Geospatial Analyses}

\author{
Ahmed M. El-Zeiny ${ }^{1^{*}}$; Hazem T. Abd El-Hamid ${ }^{2}$ and Muhammad A. El-Alfy ${ }^{2}$
}

${ }^{l}$ Environmental Studies Department, National Authority for Remote Sensing and Space Sciences (NARSS), Cairo, Egypt

${ }^{2}$ Marine Pollution Department, National Institute of Oceanography \& Fisheries, Alexandria, Egypt

\section{Reprint}

Volume 74, Number 3-4 : 89 -101

(2018) 